\title{
The Dominant Factors Influencing the Flow of Foreign Direct Investment to Indonesia
}

\author{
Makmun Syadullah, Akhmad Yasin \\ Researcher at the Fiscal Policy Agency, Ministry of Finance of the Republic of Indonesia \\ makmunsyadullah@yahoo.com, akhmadyasin08@gmail.com
}

\begin{abstract}
This paper aims to examine the impact the gross domestic product of the exporting country and the importing country, total tax rate to a commercial profit of exporting country, and importing. As for as, the object of research is the flow of FDI from four countries, namely the Netherlands, Malaysia, Singapore, and Japan to Indonesia. While the methodology used a gravity model specification to model bilateral FDI outflows. Our study finds most real GDP for both the exporting and importing country have consistently positive signs as expected, although generally, only the coefficient of the GDP of the importing country is significant. The coefficient percentage of the total tax rate to commercial profit, both in the exporting country and importing country, also in line with the theory, although both are insignificant.
\end{abstract}

Keyword: International investment, tax, economic growth, Economic Development, Fiscal, Policy, Panel Data Models.

\section{Introduction}

The diversity of corporation tax between countries is one factor that distorts investment between countries. The company must comply with tax laws in each country where it operates. Compliance with tax regulations and procedures places a heavy administrative burden on companies involved in cross-border activities, mainly because tax changes often occur. The diversity of tax regulations also creates double taxation. Although there are multiple tax agreements, problems persist, especially about the calculation of the price of transfers and restructuring of international groups, (Princen, 2012). In the debate about corporate tax reform, the discussion of each country's corporate tax and how it affects the decision of multinational companies to invest focuses on the tax rate according to the law. Although taxes are a useful proxy, they are often very different in magnitude from a more meaningful level: the average effective tax rate (Cederwall, 2015). According to Martin (2009), investment decisions can be considered as one of the most important decisions taken by financial managers. The investment decision-making process influences the firm's affirmation in the business environment and increases its market share

Investment decision concerns the issue of capital allocation for fixed assets or financial assets; central place returns to fixed assets, acquired as a result of the capital investment. Edame and Willie Wilfred Okoi (2014) examine the impact of taxation on investment and economic growth in Nigeria from 1980-2010. The result of the analysis showed that taxation is negatively related to the level of investment and the output of goods and services (GDP) and is positively related to government expenditure in Nigeria. They also observed that taxation statistically is a significant factor influencing investment, GDP and government expenditure in Nigeria. Christopher et al. (1983) in Edame and Willie Wilfred Okoi (2014), Discovered in a study of 208 British industrial companies, that the low investment experienced then was as a result of inadequate demand for funds (rather than general storage of capital) reflecting low investment opportunities. They subsequently suggested that a policy aimed at expanding the domestic demand would stimulate investment. Discovered in a bid to quantity demand, many proxies have been suggested, including sales, output, profit and others.

Investment decisions regarding capital allocation issues for both fixed assets and financial assets. According to Edame and Willie Wilfred Okoi (2014) who examined the impact of taxation on investment and economic growth in Nigeria from 1980-2010, taxation was negatively related to the level of investment and output of goods and services (GDP) and positively related to government spending. Taxation is also statistically a significant factor affecting investment, GDP, and government expenditure. Christopher et al. (1983) in Edame and Willie Wilfred Okoi (2014), in a study of 208 British industrial companies found that low investment was a result of insufficient funding requests. Indonesia is one of the world's investment destination countries. This is because Indonesia has important aspects that support a trusted investment business. Indonesia's unique attractiveness becomes its trigger for foreign investors to invest their capital. The attractiveness is embodied in important aspects of investment support such as the healthy economy, stable political situation, favourable 
investment climate, abundant natural resources, favourable demographic situation, and growing domestic market.

Based on the above background, this paper aims to examine the impact the real gross domestic product of the exporting country, the GDP of importing country. Total tax rate to a commercial profit of exporting country, and total Tax rate to a commercial profit of importing. For that will be tested against the four largest countries that invest in Indonesia, namely the Netherlands, Singapore, Japan, and Malaysia. Foreign Direct Investment (FDI) sourced from these four countries in 2015 reached USD 13,162,93 million or 44,96 per cent of total FDI into Indonesia.

\section{Literature Review}

The Impact of Taxation on the Investment: According to Bucataru (2002), investment decisions and decisionmaking processes are influenced by a number of internal and external factors.

Internal Factors: Company goals; involvement of managers and employees in submitting maximum efforts to achieve goals; the nature of the product or service offered; company characteristics; unit interdependence in achieving goals.

External Factors: According to Martin (2009) fiscal factors play an important role in the decision-making process of a company in determining where it will carry out its activities. Other aspects that are also considered include infrastructure, available labour, laws, quality of local services, etc. The company will decide to set its activities in countries where fiscal costs and production costs are cheaper. Meanwhile, according to Vartia (2008), in OECD member countries, the increase in tax rates was negatively responded by decreasing the benefits of capital depreciation through changes in user capital costs. Vartia concluded that personal and corporate income taxes have a negative effect on productivity. In contrast, tax incentives for research and development (R \& D) have a positive effect on productivity. Edame and Willie Wilfred Okoi (2014) in their study found an inverse relationship between corporate income tax and personal income tax with investment. Every one per cent increase in corporate income tax will result in a decrease in the level of investment. As a result, an increase in personal income tax will result in a decrease in the level of investment. According to the OECD cross-border FDI flows decreased 3.7 per cent after a 1 percentage point increase in the tax rate on FDI.

While the range of decreases varies greatly, which is in the range of 0per cent to 5per cent depending on the type of industry and country studied. This reflects increased capital mobility because non-tax barriers to FDI are removed. This estimate can be used to estimate the long-term impact on corporate tax reform FDI. Economic Growth and Investment: Many factors influence foreign investment, such as economic growth, market clarity in destination countries, adequate macroeconomic stability characterized by low inflation rates and stable exchange rates. Another important thing to consider is political stability in the destination country. According to Shahzad and Seilan (2013), Clegg and Scots-Green (1999) and Neubaus (2006) market size and growth variables have a significant positive effect on FDI. Whereas according to Neubaus (2006), market size affects most horizontal FDI but does not matter for vertical FDI. In contrast, Jayachandran and Seilan (2010) found that the rate of economic growth had no effect on the existence of foreign direct investment. GDP is only one of the factors that influence FDI. Previous research in Pakistan by Awan, et al. (2011), shows that GDP positively and significantly affects FDI inflows because the increase in GDP causes an increase in attractiveness of FDI to Pakistan.

\section{Research Methodology and Data}

This paper uses the specifications of the gravity model developed by Beck and Alexis Chaves (2012). According to the interests and purposes, this study does not fully use the gravity model specification used by Beck and Alexis Chaves. The author modifies, so the gravity model specification used in this paper is as follows:

$$
\ln \left(F D I_{i j t}\right)=\beta_{0}+\beta_{1} \ln G D P_{i t}+\beta_{2} \ln G D P_{j t}+\beta_{3} \ln \operatorname{Tax}_{i t}+\beta_{4} \ln \operatorname{Tax}_{j t}
$$


Where:

$F D I_{i j t} \quad$ : the value of real foreign direct investment flowing from country $i$ to country $j$ in year $t$

$\mathrm{GDP}_{\text {it }} \quad$ : the real gross domestic product of exporting country $i$ in year $t$

$\mathrm{GDP}_{\mathrm{jt}} \quad$ : $\quad$ the GDP of importing country $j$ in year $t$

$\operatorname{Tax}_{\text {it }} \quad$ : $\quad$ percentage total Tax rate to a commercial profit of exporting country $i$ in year $t$

$\operatorname{Tax}_{j t} \quad$ : $\quad$ percentage total Tax rate to a commercial profit of importing country $j$ in year $t$

FDI data is sourced from the Indonesian Investment Coordinating Board. This data does not include investments in the oil and gas sector, banking, non-banking financial institutions, insurance, leasing, investments issued by technical / sectoral agencies, and portfolios and household investments. In this paper four countries were chosen, namely the Netherlands, Malaysia, Singapore and Japan. FDI inflows from these countries account for 45 per cent of the total FDI inflows to Indonesia.

\section{Analysis}

Overview of FDI Inflows to Indonesia: National policy is the key to the attraction of FDI. In recent decades many countries have begun to liberalize especially those related to FDI policy. In some cases, FDI is just a complement to domestic investment. However, in its development, FDI has an important role in investment as a whole. The growth of FDI in Indonesia from 2010 to 2015 can be seen in Figure 1. The figure shows an increasing trend of FDI flows. This cannot be separated from a number of government regulatory incentives provided to attract investors to Indonesia such as fiscal incentive policy packages to support increased investment. The government also built Special Economic Zones (SEZs) to accommodate industrial activities, exports, imports and other economic activities that have high economic value and international competitiveness. The development of the SEZs was inspired by the success of several countries that adopted it earlier, such as China and India. Even empirical data illustrates that SEZs in the country is able to attract investors, especially foreign investors to invest and create jobs. It is none other than because of the ease that investors get, the ease of shaped ease in the field of fiscal, taxation and customs. In fact, there are also nonfiscal areas, such as ease of bureaucracy, special arrangements in the field of employment and immigration, and efficient service and order within the region.

\section{Figure 1: Statistic of Foreign Direct Investment by Country 2015 (million USD)}

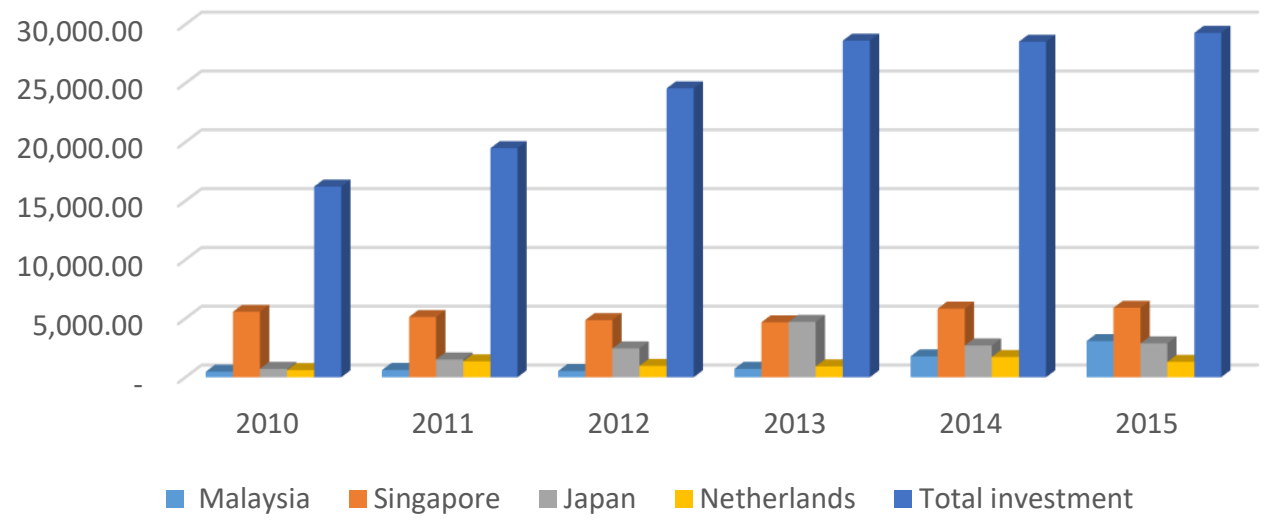

Source: Investment Coordinating Board of the Republic of Indonesia

The sectors most in demand by foreign investors are mining with a contribution of 13,72per cent), transport, storage \& communication metal (11,24per cent), machinery \& electronic industry (10,56 per cent), electricity, gas \& water supply (10,35 per cent), real estate, Ind. estate \& business activities (8,31 per cent) and Food Crops \& Plantation (7,08 per cent). Total investment in the sector reached 67.94 per cent (see Table 1). 
Table 1: Statistic of Foreign Direct Investment Realization by Sector 2016 (million USD)

\begin{tabular}{|c|c|c|c|c|c|c|}
\hline & 2010 & 2011 & 2012 & 2013 & 2014 & 2015 \\
\hline Food Crops \& Plantation & 750.96 & $1,222.49$ & $1,601.87$ & $1,605.34$ & $2,206.72$ & $2,072.02$ \\
\hline Livestock & 25.03 & 21.14 & 19.82 & 11.30 & 30.82 & 75.13 \\
\hline Forestry & 39.36 & 10.33 & 26.94 & 28.83 & 53.33 & 18.98 \\
\hline Fishery & 18.02 & 9.99 & 28.99 & 10.01 & 35.29 & 53.10 \\
\hline Mining & $2,200.55$ & $3,619.22$ & $4,255.45$ & $4,816.36$ & $4,665.10$ & $4,017.20$ \\
\hline Food Industry & $1,025.75$ & $1,104.64$ & $1,782.95$ & $2,117.74$ & $3,139.58$ & $1,521.18$ \\
\hline Textile Industry & 154.80 & 497.26 & 473.12 & 750.70 & 422.49 & 433.43 \\
\hline $\begin{array}{l}\text { Leather Goods \& } \\
\text { Footwear Industry }\end{array}$ & 130.38 & 255.01 & 158.88 & 96.19 & 210.66 & 161.58 \\
\hline Wood Industry & 43.06 & 51.14 & 76.29 & 39.50 & 63.65 & 47.11 \\
\hline $\begin{array}{lr}\text { Paper and } & \text { Printing } \\
\text { Industry } & \\
\text { Chemical } & \text { and }\end{array}$ & 46.41 & 53 & $1,306.61$ & $1,168.88$ & 706.49 & 706.93 \\
\hline $\begin{array}{l}\text { Pharmaceutical Industry } \\
\text { Rubber and Plastic }\end{array}$ & 793.36 & $1,467.40$ & $2,769.79$ & $3,142.31$ & $2,323.37$ & $1,955.75$ \\
\hline $\begin{array}{l}\text { Industry } \\
\text { Non-Metallic } \quad \text { Mineral }\end{array}$ & 104.31 & 369.96 & 660.30 & 472.22 & 543.91 & 694.47 \\
\hline $\begin{array}{l}\text { Industry } \\
\text { Metal, Machinery \& }\end{array}$ & 28.40 & 137.15 & 145.76 & 874.13 & 916.88 & $1,302.81$ \\
\hline $\begin{array}{l}\text { Electronic Industry } \\
\text { Medical Preci. \& Optical } \\
\text { Instru, Watches \& Clock }\end{array}$ & 589.51 & $1,772.78$ & $2,452.62$ & $3,327.09$ & $2,471.95$ & $3,092.49$ \\
\hline $\begin{array}{l}\text { Industry } \\
\text { Motor Vehicles \& Other } \\
\text { Transport } \quad \text { Equip. }\end{array}$ & - & 41.92 & 3.40 & 26.08 & 7.24 & 6.87 \\
\hline Industry & 393.77 & 770.13 & $1,840.05$ & $3,732.24$ & $2,061.28$ & $1,757.26$ \\
\hline Other Industry & 27.56 & 64.74 & 100.19 & 111.70 & 151.77 & 83.21 \\
\hline $\begin{array}{l}\text { Electricity, Gas \& Water } \\
\text { Supply }\end{array}$ & $1,428.62$ & $1,864.93$ & $1,514.57$ & $2,221.75$ & $1,248.81$ & $3,028.92$ \\
\hline Construction & 618.35 & 353.70 & 239.57 & 526.81 & $1,383.61$ & 954.52 \\
\hline Trade \& Repair & 773.58 & 826.00 & 483.58 & 606.50 & 866.80 & 625.05 \\
\hline Hotel \& Restaurant & 346.61 & 242.24 & 768.16 & 462.52 & 513.11 & 650.19 \\
\hline $\begin{array}{l}\text { Transport, Storage \& } \\
\text { Communication } \\
\text { Real Estate, Ind. Estate \& }\end{array}$ & $5,072.12$ & 8.86 & 08.23 & $1,449.87$ & $3,000.89$ & $3,289.89$ \\
\hline Business Activities & $1,050.36$ & 198.65 & 401.78 & 677.72 & $1,168.43$ & $2,433.58$ \\
\hline Other Services & 553.93 & 517.33 & 645.77 & 341.74 & 337.51 & 294.30 \\
\hline
\end{tabular}

Source: Investment Coordinating Board of the Republic of Indonesia.

FDI is believed to have a positive effect on the economic growth of destination countries (Effendi and Soemantri 2003). This positive impact is due to the transfer of technology and managerial skills, the introduction of new production technologies and access to international networks. For developing countries, the entry of foreign direct investment also means the ease of obtaining soft loans. But this does not apply to Venezuela, because the impact of FDI on economic productivity is very small Aitken and Harisson (1999). This finding is similar to the results of a study conducted by Germidis (1977) which states that FDI does not have a significant effect on increasing economic growth. The results of this empirical study differ from the findings obtained by Borensztein, Gregorio, and Lee (1998) which states that the existence of FDI actually increases economic growth. This finding is supported by Alfaro, Chandra, Kalemli-Ozcan, and Sayek (2000) 
who also stated that the presence of FDI had a positive impact on economic growth, especially in the financial sector. The differences in findings from several different researchers are the main attraction of researchers to conduct research on the impact of foreign direct investment in Indonesia, whether to support the hypothesis that direct foreign investment will increase economic growth or vice versa. GDP is real annual GDP obtained from an OECD national account. While the total tax rate for commercial profits is obtained from the World Bank. Unlike the previous study, the focus of this paper is not to measure the impact of FDI on economic growth but emphasizes whether economic growth factors in Indonesia are one of the driving factors for the entry of FDI.

Estimation and Result: To measure the impact of some variables that predictably affect FDI to Indonesia, the initial model used is a common effect, but the regression results indicate that there is a coefficient sign that is not in accordance with the expected, i.e the tax coefficient in the FDI exporting country is negative. After cross-section test of $\mathrm{F}$ and Cross-section Chi-square value $<0.05$, so the common effect model is rejected. GDP is the real annual GDP obtained from the OECD national accounts. While the total tax rate to commercial profit is obtained from the World Bank.

Table 2: Model Foreign Investment Ratio

\begin{tabular}{lll}
\hline Variable & Comman Effect & Cross Section Fixed Test \\
\hline Gdpothers & 0.745098 & 0.783730 \\
Gdpindo & $1.582193^{*}$ & 2.357712 \\
Taxothers & $-3.624647^{*}$ & $0.871945^{*}$ \\
Taxindo & 0.039354 & -1.088968 \\
Constant & 11.16543 & -6.434142 \\
R-squared & 0.512322 & 0.594547 \\
\hline
\end{tabular}

Source: Internal Calculation *) significant at level 5per cent

Based on Table 2, the Fixed Test Cross Section Model, all coefficients of explanatory variables have signs according to the theory. Real GDP for exporting and importing countries consistently has positive signs as expected, but only significant importing country GDP coefficients. If the exporting country's GDP increases 1 per cent, FDI outflows to Indonesia will increase by 0.75 per cent, whereas if Indonesia's GDP increases by 1per cent, FDI inflows to Indonesia will increase by 2.36 per cent. The results of this study are in line with the results of Beck's (2012) study, but in contrast to the results of research by Aitken and Harisson (1999), Germidis (1977) who found that the impact of FDI did not significantly influence economic growth. Like eggs with chicken, whichever comes first? Will FDI affect economic growth or vice versa economic growth that drives FDI inflows? Unlike previous research, this paper sees that economic growth will drive FDI inflows. This is in line with Lipsey's (1979) that investment deterrence is national income, investment level and expectations. The level of demand for goods is the main determinant Lipsey's investment argues that the higher the level of demand and income, the higher the desire among companies to invest, because of good expectations about the future.

Tax rates in exporting countries and importing countries have a negative impact on FDI but are not significant. If the percentage of the total tax rate for commercial profits in the exporting country rises by 1 per cent, then the outflow of FDI to Indonesia will increase by 0.87 per cent. The tax elasticity increase in the negative importing country is 1.09 per cent, which means that if the percentage of the total tax rate on commercial profits in Indonesia decreases by 1per cent, FDI inflows will increase by 1.09 per cent. The impact of taxation in importing countries is not statistically significant, which can mean that taxes do not play a role in attracting foreign investment. Research conducted by Martin (2009) also shows that taxation plays an important role in the investment decision-making process, but companies must also consider other aspects (infrastructure, available labour, laws, the local quality of services, etc.) if they want to be efficient. The Indonesian government also provides various incentives to facilitate investors to expand their business in Indonesia. Among them are tax holiday facilities, tax incentives, and simplification of licensing, import duty exemption facilities that are applied to imported machinery. The Indonesian government also provides tax 
allowance facilities, which are facilities provided by the government in the form of reducing the company's net income to 30 per cent of the investment value.

\section{Conclusion and Recommendations}

Conclusion: Some conclusions from this study are: First, real GDP for exporting and importing countries has positive signs consistently as expected, but only the import coefficient of GDP of the country is significant. This finding shows that the higher the economic growth in the destination country, the higher the company's desire to invest, because of good expectations about the future. Second, the tax rate coefficient in both the exporting country and the importing country has a negative impact, but the effect is not significant. Taxation plays an important role in the decision making process investment, but companies must also consider other aspects (infrastructure, available labour, laws, quality of local services, etc.) Want to be efficient.

Recommendations: Based on the findings above, the Indonesian government needs to develop a strategy to accelerate and develop economic development that can be pursued through First, developing economic development corridors by building economic centres on each island. In addition to developing industrial clusters based on commodity and sector advantages. Second, strengthen national relations both locally and internationally. This can reduce transaction costs, create synergies between centres of growth and overcome access to services. Like intro and inter-connectivity between growth centres and international trade and tourism doors. While in terms of taxation, the government has provided a number of incentives to foreign investors. This strategy can be further developed by providing incentives to sectors that are less developed but attracted by foreign investors.

\section{References}

Aitken, B. J. \& Harrison, A. (1999). Do domestic firms benefit from direct foreign investment? Evidence from Venezuela. American economic review, 89, 605-618.

Alfaro, L., Chandra, A., Kalemli-Ozcan, S. \& Sayek, S. (2000). FDI and economic growth: The role of local financial markets. Harvard Business School. Working Paper, 01-083.

Awan, Muhammad Zahid, Bakhtiar Khan. \& Khair, uz Zaman. (2011). Economic determinants of foreign direct investment(FDI) in commodity producing sector: A case study of Pakistan, African Journal of Business Management, 5(2), 537-545.

Beck, Stacie. \& Alexis, Chaves. (2012). The Impacts of Various Taxes on Foreign Direct Investment, U.S. Bureau of Economic Analysis or the U.S. Department of Commerce.

Borensztein, E., De Gregorio, J. \& Lee, J. W. (1998). How does foreign direct investment affect economic growth? Journal of international economics, 45, 115-35.

Bucătaru, Dumitru. (2002). Gestiunea financiară a întreprinderii, Partea I, Sedcom Libris Publ. H., Iasi.

Cederwall, Eric. (2015). How Taxes Affect Investment Decisions For Multinational Firms.

Christopher, M., Carolyn, A. \& Brunm, S. (2003). Impact of corporate tax on economic development - Crowy Williams Publication, Geneva U.S.A.

Clegg, J. \& Scott-Green. (1999). The Determinant a New FDI Capital Flow into the EC: A Statistical Comration of the USA and Japan, Journal of Common Market Studies, 37(4), 597-616.

Edame, Greg Ekpung. \& Willie, Wilfred Okoi. (2014). The Impact of Taxation on Investment and Economic Development in Nigeria, Academic Journal of Interdisciplinary Studies MCSER Publishing, Rome-Italy, 3(4), 209-2018.

Effendi, N. \& Soemantri, F. M. (2003). Foreign direct investment and regional economic growth in Indonesia: A panel data study. Working paper in economics and development studies.

Germidis, D. (1977). Transfer of technology by multinational corporations. Development centre of organization for economic cooperation and development. Paris.

Jayachandran, G. \& Seilan, A. (2010). A Causal Relationship between Trade, Foreign Direct Investment and Economic Growth for India. International Research Journal of Finance and Economics, 42, 75-88.

Lipsey, R. G. (1979). Tax evasion and its effects on the economy. Joanne publishers Ltd. Onitsha. Miscellaneous taxation provision Decree 1985. 


\section{Journal of Social and Development Sciences (ISSN 2221-1152)}

Vol. 9, No. 4, pp. 36-42, December 2018

Martin, Adina. (2009). The Impact of Taxation on the Investment Localization Decision in the Context of Globalization, Analele Stiinłifice ALE Universităłii. Alexandru Ioan Cuza” Din Iasi Tomul LVI Stiinńe Economics, 133-142.

Neubaus, M. (2006). The Impact of Foreign Direct Investment on Economic Growth: An Analysis for the Transition countries of Central and Eastern Europe, Physical Verlag HD, 141-151.

Princen, Savina. (2012). Determining the impact of taxation on corporate financial decision-making, Reflets et perspectives de la vie économique $3,161-170$.

Shahzad, A. \& Al-Swidi, A. K. (2013). Effect of Macroeconomic Variables on the FDI inflows: The Moderating Role of Political Stability: An Evidence from Pakistan. Asian Social Science, 9(9), 270-279.

Vartia, Laura. (2008). How do Taxes Affect Investment and Productivity? An Industry-Level Analysis of OECD Countries, OECD-Economics Department Working Papers, 656. 